\title{
Influence of feed restriction in primiparous lactating sows on body condition and metabolic parameters
}

\author{
Hélène Quesnel*, Anne Pasquier, Anne-Marie Mounier, \\ Isabelle Louveau, Armelle Prunier
}

Station de recherches porcines, Inra, 35590 Saint-Gilles, France

(Received 4 November 1997; accepted 7 April 1998)

\begin{abstract}
Twenty-four primiparous sows were allocated at farrowing to a high $(\mathrm{H}: 5.5-6 \mathrm{~kg}$ feed/day) or a low (L: $2.5-3 \mathrm{~kg} /$ day) level of feeding. Litters (8-10 piglets) were weaned at $28 \pm 2$ days. Serial blood samples were collected 1 day before weaning $(W-1)$, in the hours following weaning $(\mathrm{W})$ and 1 day after $(\mathrm{W}+1)$. L sows lost significantly more weight (38 versus $15 \mathrm{~kg}$ ) and backfat ( 5.3 versus $2.3 \mathrm{~mm}$ ) during lactation than $\mathrm{H}$ sows. On day $\mathrm{W}-1, \mathrm{~L}$ sows had higher mean concentrations of NEFA $(P<0.01)$ and $\mathrm{GH}(P<0.1)$ and lower concentrations of insulin and IGF-I $(P<0.05)$ than $\mathrm{H}$ sows. Mean concentrations of glucose and cortisol did not differ between groups of sows. On day $W+1$, these parameters were not different between treatments, except IGF-I concentrations which remained lower in $\mathrm{L}$ than in $\mathrm{H}$ sows $(P<0.05)$. We conclude that lactating primiparous sows alter secretion of metabolic hormones to favour mobilization of body reserves to support milk production. Low insulin and IGF-I may be involved in reduced ovarian activity at and after weaning, through LH-dependent and independent pathways. $\odot$ Inra/Elsevier, Paris
\end{abstract}

sow / food restriction / lactation / metabolic parameters

Résumé - Influence du rationnement alimentaire sur les paramètres métaboliques de truies primipares. Vingt-quatre truies primipares sont nourries pendant la lactation selon un plan d'alimentation proche du niveau ad libitum (lot $\mathrm{H}$ ) ou reçoivent environ $50 \%$ de cette ration (lot $\mathrm{L}$ ). Les porcelets (8-10 par portée) sont sevrés à $28 \pm 2 \mathrm{j}$. Des prélèvements de sang sériés sont effectués la veille du sevrage, dans les heures qui suivent le sevrage et le lendemain du sevrage. Les truies du lot $\mathrm{L}$ perdent significativement plus de poids ( 38 versus $15 \mathrm{~kg}$ ) et de lard $(5,3$ versus $2,3 \mathrm{~mm}$ ) pendant la lactation que celles du lot $\mathrm{H}$. La veille du sevrage, les truies du lot $\mathrm{L}$ ont des concentrations plus élevées d'acides gras libres $(p<0,01)$ et de $\mathrm{GH}(p<0,1)$ et des concentrations plus faibles d'insuline et d'IGF-I $(p<0,05)$ que celles du lot $\mathrm{H}$. Les concentrations moyennes de glucose et de cortisol sont similaires dans les deux lots. Le lendemain du sevrage, ces paramètres ne diffèrent plus entre les traitements, sauf l'IGF-I qui reste à des concentrations

* Correspondence and reprints

E-mail: quesnel@st-gilles.rennes.inra.fr 
plus faibles chez les truies du lot $\mathrm{L}(p<0,05)$. Nous concluons que les truies en première lactation présentent des modifications de la sécrétion des hormones métaboliques qui favorisent la mobilisation des réserves maternelles afin d'assurer la production du lait. Les faibles concentrations d'insuline et d'IGF-I peuvent être impliquées dans l'inhibition de l'activité ovarienne au sevrage et après, via des mécanismes dépendants ou non de LH. (C) Inra/Elsevier, Paris

truie / restriction alimentaire / lactation / paramètres métaboliques

\section{INTRODUCTION}

In sows, lactation is associated with numerous metabolic adjustments under endocrine control. In general, lactating sows have high nutrient requirements for milk production and spontaneous feed intake is too low to meet these requirements [16]. The immediate consequence is mobilization of fat and protein body reserves, which may be sufficient to maintain a high level of milk production [12, $33,50]$. However, decrease in milk yield or in litter growth have also been observed $[27,49]$. Catabolism of body reserves as well as partition of nutrients are under the control of numerous metabolic hormones $[13,23]$. Among these, insulin, hormones from the somatotropic axis (GH, IGF-I) and corticosteroids play an important role. Although patterns of variations of these hormones during lactation and after weaning have been already described, there is no complete description of sows submitted to a high level of nutrient deficit which influences milk production. In addition to its influence on milk production, nutrient deficit may result in inhibition of the reproductive axis $[20,21,38,39]$. Reducing feed intake during lactation induces an increase in the duration of the weaning-to-oestrus interval, and a decrease in conception rate and in embryonic survival during the subsequent gestation $[17$, $24,26]$. There is now evidence that the physiological signals providing a link between nutrition during lactation and subsequent reproductive performance involve metabolic hormones and substrates [8, 23]. Therefore, the aim of the present experiment was to study metabolites and meta- bolic hormones in primiparous sows around weaning.

\section{MATERIALS AND METHODS}

\subsection{Animals and experimental design}

Crossbred Piétrain $\times$ Large White gilts were inseminated at $233 \pm 3$ days of age and $125 \pm 5 \mathrm{~kg}$ live weight (mean $\pm \mathrm{SD}$ ) for the first replicate $(n=12)$ and at $249 \pm 24$ days and $142 \pm 9 \mathrm{~kg}$ for the second replicate $(n=12)$. During the whole experiment, these primiparous females were reared under artificial light provided by incandescent lamps. Light duration decreased from 12 to $8 \mathrm{~h} /$ day between 21 and 107 days of gestation and remained constant thereafter $(8 \mathrm{~h} /$ day $)$. From 107 days of gestation, females were tethered in individual farrowing crates. Within 2 days of farrowing, litter size was standardized to 9-10 piglets by cross-fostering. Piglets always had free access to water and after 21 days of age, they had also free access to a standard creep feed. They were weaned between 0830 and 1000 hours at $28 \pm 2$ days of age.

During gestation, all females received $2.7 \mathrm{~kg} /$ day of a diet containing $12.6 \mathrm{MJ} \mathrm{DE} / \mathrm{kg}$, $13.2 \%$ crude protein and $0.6 \%$ lysine. Gilts were paired according to mating weights and were assigned at farrowing either to a low (L, $n=6 /$ replicate $)$ or to a high (H, $n=6 /$ replicate) scale of feeding (table $I$ ). Throughout lactation, sows received twice daily, at 0830 and 1500 hours, a diet containing 13.1 MJ $\mathrm{DE} / \mathrm{kg}, 17.1 \%$ crude protein and $0.9 \%$ lysine (table II). Feed refusals did not occur in the $\mathrm{L}$ group and seldom occurred in the $\mathrm{H}$ group, but were not measured. From the day of weaning, the females received $3 \mathrm{~kg} /$ day of the gestation diet, in two equal meals distributed at 0830 and 1500 hours.

Among the 24 sows, 12 were slaughtered on the day of weaning and 12 were slaughtered $48 \mathrm{~h}$ after weaning, for ovarian removal [40]. 
Table I. Daily feed allowance $(\mathrm{kg})$ during lactation and after weaning.

\begin{tabular}{lcc}
\hline \multicolumn{1}{c}{ Stage } & H group & L group \\
\hline At farrowing & 1.0 & 1.0 \\
1 day postpartum & 2.5 & 2.5 \\
2 days postpartum & 4.0 & 2.5 \\
3 to 12 days postpartum & 5.0 & 2.5 \\
13 to 15 days postpartum & 5.5 & 2.5 \\
15 to 28 days postpartum & 6.0 & 3.0 \\
Day of weaning & 3.0 & 3.0 \\
Day after weaning & 3.0 & 3.0 \\
\hline
\end{tabular}

Table II. Composition of the diet during lactation.

\begin{tabular}{lc}
\hline Ingredient, \% (air-dried basis) & \\
\hline Barley & 25.00 \\
Wheat & 22.80 \\
Yellow corn & 12.00 \\
Soybean meal & 21.00 \\
Wheat bran & 10.00 \\
Beat molasse & 3.00 \\
Fat & 2.00 \\
Calcium carbonate & 1.30 \\
Dicalcium phosphate & 1.90 \\
Salt & 0.45 \\
Trace mineral and vitamins ${ }^{\mathrm{a}}$ & 0.50 \\
L-Lysine Hcl (78\%) & 0.05 \\
Analysed levels (as fed) & \\
Dry matter (\%) & 88.2 \\
Organic matter (\%) & 70.2 \\
Crude protein (\%) & 17.1 \\
Digestible energy (MJ/kg) & 13.1 \\
Amino acids content & \\
Lysine (\%) & \\
Methionine+cystine (\%) & 0.90 \\
Threonine (\%) & 0.60 \\
\hline
\end{tabular}

a Provided the following amounts of trace elements in milligrams per kilogram: $80 \mathrm{mg}$ of iron; $10 \mathrm{mg}$ of copper; $40 \mathrm{mg}$ of manganese; $100 \mathrm{mg}$ of zinc; $0.1 \mathrm{mg}$ of cobalt; $0.6 \mathrm{mg}$ of iodine; $0.15 \mathrm{mg}$ of selenium; and vitamins in units or milligrams per day: vitamin A, $10000 \mathrm{IU}$; vitamin D3, $1500 \mathrm{IU}$; vitamin E, $30 \mathrm{mg}$; vitamin K3, $2 \mathrm{mg}$; thiamin, $2 \mathrm{mg}$; riboflavin, $4 \mathrm{mg}$; nicotinic acid, $15 \mathrm{mg}$; d-pantothenic acid, $10 \mathrm{mg}$; pyridoxine, $3 \mathrm{mg}$; d-biotin: $0.2 \mathrm{mg}$; folic acid, $3 \mathrm{mg}$; vitamin B $12,0.02 \mathrm{mg}$; choline: $500 \mathrm{mg}$; ${ }^{\mathrm{b}}$ calculated values (Inra, 1989).

\subsection{Sample collection}

Jugular vein catheterization was performed under general anaesthesia at around day 8 of lactation. Sows were deprived of feed on the day of surgery and then refed. Catheters were rinsed daily with physiological serum contai- ning sodium heparin (190 IU/mL) and antibiotics. Blood samples were collected in heparinized tubes for $6 \mathrm{~h}$ from 1000 to 1600 hours during 3 consecutive days around weaning ( 1 day before weaning $\mathrm{W}-1: n=24$; day of weaning $\mathrm{W}: n=12 ; 1$ day after weaning $\mathrm{W}+1$ : $n=12$ ). The volume of blood collection was 
$5 \mathrm{~mL}$ from 1000 to 1550 hours and $10 \mathrm{~mL}$ at 1600 hours. Samples were immediately placed on ice and centrifuged to remove plasma. Plasma samples were stored at $-20{ }^{\circ} \mathrm{C}$ until assayed. Blood of one $\mathrm{H}$ sow could not be collected because its catheter was not functional.

\subsection{Analyses}

\subsubsection{Measurements}

The sows were weighed and fat thickness was ultrasonically measured at three sites (shoulder, back and loin, at $65 \mathrm{~mm}$ from the midline) 1 day after farrowing and at weaning. Piglets were weighed at birth, at 21 days of age and at weaning.

\subsubsection{Hormone assays}

Concentrations of $\mathrm{GH}$ and insulin were measured every $20 \mathrm{~min}$, concentrations of nonesterified fatty acids (NEFA) and glucose every hour, and concentrations of cortisol and IGF-I once daily (at 1500 hours and 1600 hours, respectively). Samples were analysed in duplicate within one assay/replicate for insulin and $\mathrm{GH}$ and within a single assay for cortisol and IGF-I. Plasma insulin, GH and cortisol concentrations were determined in plasma samples by validated RIAs $[30,31,35]$. Concentrations of IGF-I were determined in plasma using a double antibody RIA after an acid-ethanol extraction as previously described [29]. For insulin, the intra- and interassay CVs were 6.3 and $19.1 \%$ at $167 \mu \mathrm{IU} / \mathrm{mL}$, respectively, and for $\mathrm{GH}, 5.1$ and $12.9 \%$ at $4.3 \mathrm{ng} / \mathrm{ml}$, respectively. For cortisol and IGF-I, the intraassay CVs were $3.3 \%$ at $22 \mathrm{ng} / \mathrm{mL}$ and $8.8 \%$ at $41 \mathrm{ng} / \mathrm{mL}$, respectively. Average sensitivities, estimated as $90 \%$ of total binding, were $2 \mu \mathrm{IU} / \mathrm{mL}$ for insulin, $0.75 \mathrm{ng} / \mathrm{mL}$ for $\mathrm{GH}, 2.5 \mathrm{ng} / \mathrm{mL}$ for cortisol and $4 \mathrm{ng} / \mathrm{mL}$ for IGF-I.

\subsubsection{Metabolite assays}

Concentrations of glucose and NEFA were measured by automatic enzymatic methods with a Cobas Mira (Hoffman Laroche, Basel, Switzerland) apparatus.

\subsection{Statistical analyses}

All data (sow and litter parameters, blood concentrations) were analysed by analysis of variance using the GLM procedure of SAS [43]. All models included the effects of feeding level and replicate and the interaction between these two factors. For litter weight gain, the number of piglets was introduced as a covariate in the analysis. For NEFA, glucose and insulin, two types of analyses were conducted, in order to study variations between individual samples (time courses variations) and between mean concentrations calculated on the overall profiles. For individual samples, a split-plot design was used, including the effect of sow nested within feeding level $\times$ replicate (error to test the effects of feeding level, replicate and any interactions), sampling time and all interactions as sources of variation. These analyses were repeated on days $\mathrm{W}-1, \mathrm{~W}$ and $\mathrm{W}+1$. For IGF-I and cortisol, and mean concentrations of NEFA, glucose, insulin and GH, a split-plot design was used with day of sampling instead of sampling time within day. When an interaction tended to be significant $(P<0.1)$, the effects were studied separately. When the effect of day of sampling was significant $(P<0.05)$, comparisons between days were realized with the Bonferroni test. Pearson correlation coefficients were calculated between metabolic parameters and reproductive characteristics earlier described [40].

\section{RESULTS}

\subsection{Sow and litter performance}

At farrowing, there was no significant difference in live weight and backfat depth (means of fat depth at three sites) between sows allocated to high or low levels of feeding. During lactation, the decrease in live weight and in backfat depth was higher in $\mathrm{L}$ than in $\mathrm{H}$ sows (table III). Therefore, $\mathrm{L}$ females were lighter $(P<0.001)$ and had less backfat $(P<0.01)$ than $\mathrm{H}$ females at weaning.

Litter size at weaning was similar for $\mathrm{H}$ and $\mathrm{L}$ sows (table IV). For this reason, the number of piglets was introduced as a covariate in the analysis of litter weight 
and daily growth. Litter live weights were similar in both groups after cross-fostering ( $48 \mathrm{~h}$ postpartum), on day 22 postpartum and at weaning. Daily weight gain of litters did not differ between treatments during the first 3 weeks of lactation. It was lower for $\mathrm{L}$ than $\mathrm{H}$ sows during the fourth week of lactation $(P<0.1)$ and during the whole lactation $(P<0.05)$.

\subsection{Metabolites}

Because plasma concentrations of NEFA and glucose exhibit time-related fluctuations, they were presented as time courses of serial sampling (figure 1 ). Independent of treatment or day, plasma concentrations of NEFA decreased after the afternoon meal (1440 versus 1540 hours,

Table III. Influence of feeding level of sows during lactation on their body condition (mean \pm SD).

\begin{tabular}{|c|c|c|c|c|}
\hline & \multicolumn{2}{|c|}{ Feeding group } & \multicolumn{2}{|c|}{ Statistical significance } \\
\hline & $\mathrm{H}$ & $\mathbf{L}$ & $\mathrm{FL}^{\mathrm{b}}$ & $\operatorname{Rep}^{\mathfrak{c}}$ \\
\hline Number of sows & 12 & 12 & & \\
\hline $\begin{array}{l}\text { Live weight }(\mathrm{kg}) \\
\text { at farrowing } \\
\text { at weaning } \\
\text { loss }\end{array}$ & $\begin{array}{l}184 \pm 11 \\
169 \pm 11 \\
-15 \pm 6\end{array}$ & $\begin{array}{l}179 \pm 12 \\
141 \pm 16 \\
-38 \pm 9\end{array}$ & $\begin{array}{l}\text { NS } \\
* * * \\
* * *\end{array}$ & $\begin{array}{l}* * \\
* * \\
* *\end{array}$ \\
\hline $\begin{array}{l}\text { Fat depth }(\mathrm{mm}) \\
\text { at farrowing } \\
\text { at weaning } \\
\text { loss }\end{array}$ & $\begin{array}{l}14.9 \pm 2.3 \\
12.5 \pm 2.1 \\
-2.3 \pm 1.4\end{array}$ & $\begin{array}{l}15.9 \pm 2.3 \\
10.4 \pm 2.0 \\
-5.3 \pm 2.4\end{array}$ & $\begin{array}{l}\text { NS } \\
* * \\
* *\end{array}$ & $\begin{array}{c}* \\
* \\
\text { NS }\end{array}$ \\
\hline
\end{tabular}

${ }^{\mathrm{a}}$ NS: $P>0.1, *: P<0.05, * *: P<0.01, * * *: P<0.001 ;{ }^{\mathrm{b}}$ effect of feeding level; ${ }^{\mathrm{c}}$ effect of replicate; ${ }^{\text {bc }}$ FL $\times$ Rep: NS.

Table IV. Influence of feeding level of sows during lactation on their litter performance (mean \pm SEM).

\begin{tabular}{|c|c|c|c|c|}
\hline & \multicolumn{2}{|c|}{ Feeding group } & \multicolumn{2}{|c|}{ Statistical significance } \\
\hline & $\mathrm{H}$ & $\mathrm{L}$ & $F L^{b}$ & $\operatorname{Rep}^{\mathfrak{c}}$ \\
\hline Number of sows & 12 & 12 & & \\
\hline Litter size after fostering & $8.8 \pm 0.3$ & $9.5 \pm 0.8$ & NS & NS \\
\hline Litter size at weaning & $8.3 \pm 0.2$ & $8.5 \pm 1.2$ & NS & NS \\
\hline $\begin{array}{l}\text { Litter live weight }(\mathrm{kg}) \\
\text { at } 48 \mathrm{~h} \text { postpartum } \\
\text { at } \mathrm{d} 22 \text { postpartum } \\
\text { at weaning }\end{array}$ & $\begin{array}{l}11.0 \pm 0.5 \\
52.0 \pm 2.2 \\
65.1 \pm 2.9\end{array}$ & $\begin{array}{l}11.5 \pm 0.5 \\
50.9 \pm 2.4 \\
61.2 \pm 2.7\end{array}$ & $\begin{array}{l}\text { NS } \\
\text { NS } \\
\text { NS }\end{array}$ & $\begin{array}{l}\text { NS } \\
\text { NS } \\
\text { NS }\end{array}$ \\
\hline $\begin{array}{l}\text { Daily litter weight gain }(\mathrm{g} / \mathrm{d}) \\
\text { during the first } 3 \text { weeks } \\
\text { during the } 4 \text { th week } \\
\text { during the whole lactation }\end{array}$ & $\begin{array}{l}1860 \pm 85 \\
2730 \pm 307 \\
2060 \pm 96\end{array}$ & $\begin{array}{l}1790 \pm 96 \\
2150 \pm 270 \\
1880 \pm 99\end{array}$ & $\begin{array}{l}\text { NS } \\
\text { T } \\
*\end{array}$ & $\begin{array}{l}\mathrm{T} \\
* * \\
* *\end{array}$ \\
\hline
\end{tabular}

${ }^{\mathrm{a}} \mathrm{NS}: P>0.1, \mathrm{~T}: P<0.1, *: P<0.05 .{ }^{* *}: P<0.01$; $^{\mathrm{b}}$ effect of feeding level; ${ }^{\mathrm{c}}$ effect of replicate; ${ }^{\text {bc }} \mathrm{FL} \times$ Rep: NS. 
$P<0.05$ ). On day $\mathrm{W}-1$, NEFA concentrations before the meal were higher in $\mathrm{L}$ than in $\mathrm{H}$ sows (figure 1 ). On days $\mathrm{W}$ and $W+1$, NEFA concentrations did not differ between groups of sows between 1140 and 1540 h (figure I). Mean concentrations of plasma NEFA were significantly influenced by the day of sampling (table V), in that they were higher on day $\mathrm{W}$ than on day $\mathrm{W}-1$ or $\mathrm{W}+1$ (figure 2).

Independent of treatment or day, plasma glucose was lower before the afternoon meal than after (1440 versus 1540 hours, $P<0.05$ ). Mean concentrations of glucose did not differ between groups of sows, but there was a significant interaction between the level of feeding and the day of sampling (table $V$, figure 2).

\subsection{Metabolic hormones}

Plasma concentrations of insulin were high after the morning meal (from 1000 to 1200 hours) and returned to the basal levels within $3 \mathrm{~h}$ of this meal, in both groups of sows, regardless of the day of sampling (figure 1). The concentrations of insulin observed after the morning meal until 1300 hours were lower in $\mathrm{L}$ than in $\mathrm{H}$ sows on day W-1 (figure I), whereas the insulin concentrations did not significantly differ between groups of sows at any time on days $\mathrm{W}$ and $\mathrm{W}+1$ (figure 1 ). There was an interaction between the level of feeding and the day of sampling for mean concentrations of insulin (table $V$ ). Mean concentrations did not significantly differ between the 3 days of sampling in $\mathrm{H}$ sows, whereas they increased progressively after weaning in $\mathrm{L}$ sows $(P<0.05$; figure 2).

Mean plasma levels of GH tended to be higher in $\mathrm{L}$ than in $\mathrm{H}$ sows on day W-1 $(P<0.1$; table $V I)$, but did not differ between groups after weaning (figure 2). Plasma GH levels were significantly higher on day $\mathrm{W}-1$ than on days $\mathrm{W}$ and
$\mathrm{W}+1$ in $\mathrm{L}$ sows, but did not differ between days in $\mathrm{H}$ sows (table $V$, figure 2).

Plasma concentrations of IGF-I were strongly influenced by the level of feeding (table V), in that they were higher in $\mathrm{H}$ than in L sows, regardless of the day of sampling $(P<0.05$, table $V I)$, and did not differ between days.

Plasma concentrations of cortisol were similar for both levels of feeding (figure 2). They decreased between day $\mathrm{W}$ and day $\mathrm{W}+1$ in both groups of sows $(P<0.05$, figure 2$)$.

\subsection{Relationships between metabolic criteria and reproductive data}

The number of LH pulses on days W-1 and $\mathrm{W}$ was positively correlated with mean concentrations of insulin $(P<0.01)$ and cortisol $(P<0.05)$, respectively, and mean FSH on day W-1 was correlated with mean GH $(P<0.05$; table VII $)$. The number of $\mathrm{LH}$ pulses on day $\mathrm{W}+1$ was negatively correlated with fat loss during lactation $(P<0.05)$.

Weight loss during lactation was negatively correlated with ovarian macroscopic characteristics (ovarian weight and follicular diameters; $P<0.05$ ) at weaning, but not $48 \mathrm{~h}$ after (table VIII). There was no significant correlation between mean concentrations of cortisol and glucose and ovarian features. Mean insulin was positively correlated with ovarian weight $(P<0.05)$, and mean NEFA negatively with the diameter of the ten largest follicles at weaning $(P<0.05$; table VIII). Plasma IGF-I on day $\mathrm{W}-1$ was positively correlated with ovarian weight at weaning $(P<0.01)$, the maximum follicular diameter at weaning and $48 \mathrm{~h}$ later ( $P<0.05$ and $P<0.01$, respectively), and the diameter of the ten largest follicles after weaning $(P<0.05$; table VIII $)$. A clear positive correlation appeared between plasma IGF-I on day W-1 and IGF- 


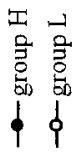

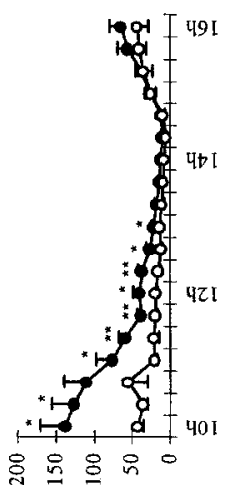
([w//חII) un!nstr

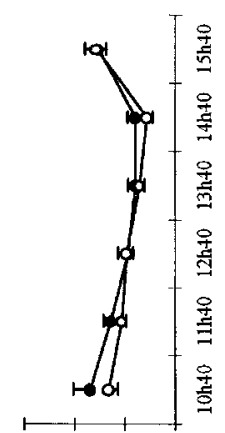

용 \&

(I/oru) asomnto)

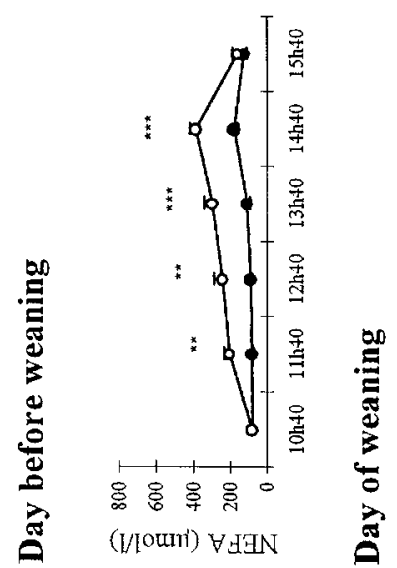

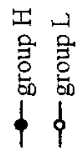
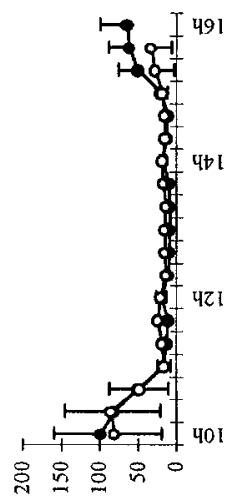

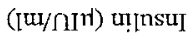

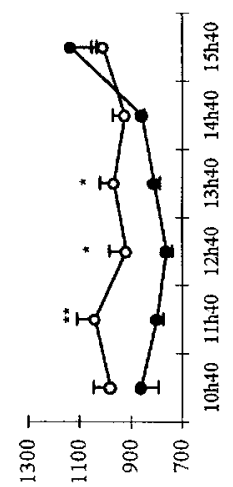

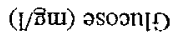

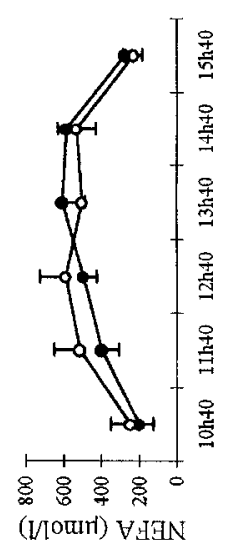

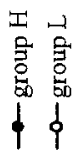

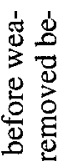

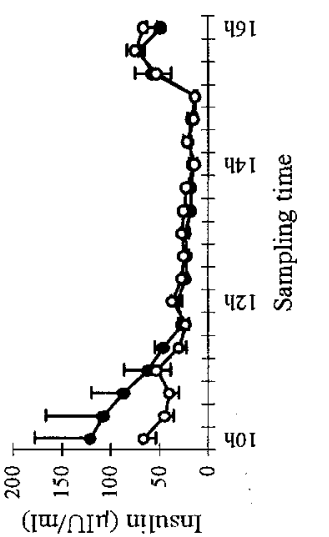

当 む

$-3$

客竞

6

II

$\Xi \cdot \Xi$

깅

需

6 종

$\Xi \pm$

䨐

틀

용요

\%

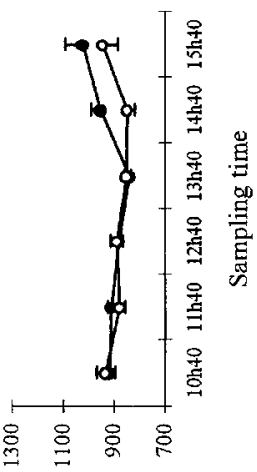

(1//8ur) วsoon[โ)

造 $000 \%$

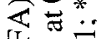

岌 号通

Z证

另起

远:

氙芯苍

Tै

远远

S 00

竞吉

tᄒ 3

$\infty 0$

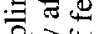

窟它

踏苞

急忌苗

范紫

啳

38

可呺

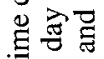

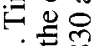

$-\underset{0}{0}$

응

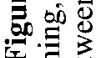


$I$ in fluid of follicles measuring at least $3 \mathrm{~mm}$ in diameter on days $\mathrm{W}$ and $\mathrm{W}+2$ $(P<0.001$; table VIII). Conversely, follicular IGF-I on day $\mathrm{W}+2$ was negatively
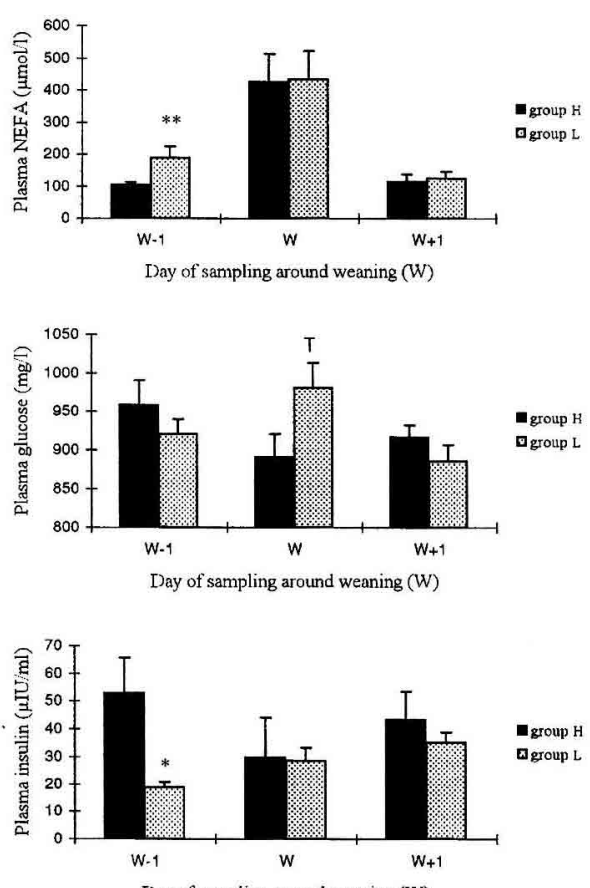

Day of sampling around weaning (W) correlated with GH on day W-1 $(P<0.05)$ and weight loss during lactation $(P<0.01$; table VIII $)$. There was no correlation between metabolic criteria and
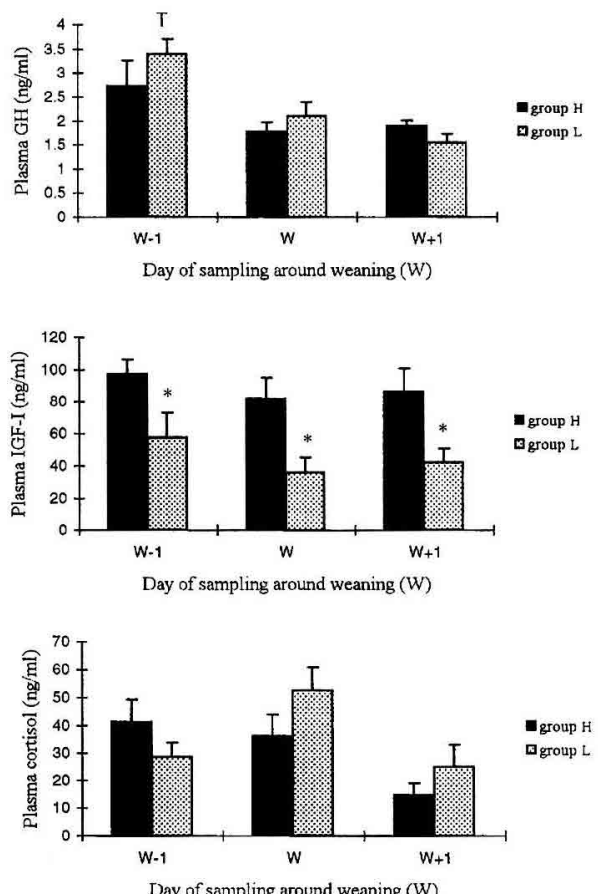

Day of sampling around weaning (W)

Figure 2. Mean concentrations ( \pm SEM) of non-esterified fatty acids (NEFA), glucose, insulin, $\mathrm{GH}$, IGF-I and cortisol in $\mathrm{H}(n=6)$ and $\mathrm{L}(n=6)$ sows 1 day before weaning (W-1), on the day of weaning (W) and 1 day after $(\mathrm{W}+1)$. Effect of feeding level: T: $P<0.1{ }^{*}: P<0.05 ; * *: P<$ 0.01 .

Table V. Significance of the effects of feeding level, replicate and day of sampling, and any interactions on mean plasma concentrations of non-esterified fatty acids (NEFA), glucose, insulin, GH, IGF-I and cortisol. Analyses were conducted on 12 sows.

\begin{tabular}{lccccc}
\hline & \multicolumn{5}{c}{ Significance of effects } \\
\cline { 2 - 6 } & $\mathrm{FL}^{\mathrm{a}}$ & $\operatorname{Rep}^{\mathrm{b}}$ & $\mathrm{FL} \times \mathrm{Rep}^{\mathrm{ab}}$ & $\mathrm{D}^{\mathrm{c}}$ & FL $\times \mathrm{D}^{\mathrm{ac}}$ \\
\hline NEFA & $*$ & NS & NS & $* * *$ & NS \\
Glucose & NS & NS & NS & NS & $*$ \\
Insulin & $*$ & NS & NS & T & $* * *$ \\
GH & NS & NS & NS & $* * *$ & $*$ \\
IGF-I & $* * *$ & NS & T & T & NS \\
Cortisol & NS & NS & NS & $* *$ & T \\
\hline
\end{tabular}

NS: $P>0.1, \mathrm{~T}: P<0.1,{ }^{*}: P<0.05,{ }^{* *}: P<0.01,{ }^{* * *}: P<0.001 ;{ }^{\mathrm{a}}$ effect of feeding level; ${ }^{\mathrm{b}}$ effect of replicate $;{ }^{\mathrm{c}}$ effect of day of sampling. 
Table VI. Influence of feeding level on mean concentrations of NEFA, glucose, insulin, GH (means from profiles) and, IGF-I and cortisol (from one sampling) in $\mathrm{H}(n=11)$ and $\mathrm{L}(n=12)$ sows on the day before weaning (mean \pm SEM)

\begin{tabular}{lccc}
\hline & \multicolumn{2}{c}{ Feeding group } & Statistical \\
\cline { 2 - 3 } & $\mathrm{H}$ & $\mathrm{L}$ & significance $^{\mathrm{ab}}$ \\
\hline NEFA $(\mu \mathrm{mol} / \mathrm{L})$ & $109.5 \pm 6.3$ & $229.1 \pm 18.2$ & $* * *$ \\
Glucose $(\mathrm{mg} / \mathrm{L})$ & $933.2 \pm 19.2$ & $906.1 \pm 13.7$ & NS \\
Insulin $(\mu \mathrm{IU} / \mathrm{mL})$ & $48.3 \pm 4.1$ & $22.9 \pm 2.0$ & $* *$ \\
GH $(\mathrm{ng} / \mathrm{mL})$ & $2.7 \pm 0.3$ & $3.3 \pm 0.2$ & $\mathrm{~T}$ \\
IGF-I $(\mathrm{ng} / \mathrm{mL})$ & $97.2 \pm 8.7$ & $57.4 \pm 15.7$ & $*$ \\
Cortisol $(\mathrm{ng} / \mathrm{mL})$ & $35.4 \pm 5.1$ & $25.9 \pm 3.0$ & $\mathrm{NS}$ \\
\hline
\end{tabular}

${ }^{\mathrm{a}}$ Effect of feeding level; NS: $P>0.1, \mathrm{~T}: P<0.1 ; *: P<0.05,{ }^{* *}: P<0.01,{ }^{* * *}: P<0.001 ;{ }^{\mathrm{b}}$ no effects of replicate and interaction between feeding level and replicate were found.

Table VII. Coefficients of correlation between the metabolic criteria observed 1 day before weaning $(\mathrm{W}-1)$ and the frequency of LH pulses and FSH concentrations measured 1 day before weaning, on the day of weaning $(\mathrm{W})$ and 1 day after weaning $(\mathrm{W}+1)$, in $\mathrm{H}$ and $\mathrm{L}$ sows $(n=12)$.

Lactational

Item GH IGF-I Insulin Cortisol Glucose NEFA Weight loss Fat loss

\begin{tabular}{lrrrlrrrr}
\hline LH pulses/6 h & & & & & & & \\
W-1 & -0.00 & 0.10 & $0.60^{* *}$ & 0.12 & 0.26 & -0.26 & -0.26 & -0.30 \\
W & 0.10 & -0.11 & 0.17 & $0.61^{*}$ & 0.07 & -0.24 & -0.27 & -0.38 \\
W+1 & -0.37 & 0.15 & -0.19 & 0.06 & -0.47 & -0.48 & -0.33 & $-0.65^{*}$ \\
& & & & & & & & \\
FSH & & & & & & & & \\
W-1 & $0.49^{*}$ & -0.28 & 0.18 & -0.09 & -0.02 & -0.09 & 0.06 & -0.06 \\
W & 0.24 & -0.23 & 0.28 & 0.06 & 0.06 & -0.27 & -0.22 & -0.51 \\
W+1 & 0.53 & -0.79 & 0.03 & 0.02 & -0.25 & -0.19 & 0.22 & -0.06 \\
\hline
\end{tabular}

$*: P<0.05, * *: P<0.01$.

the number of small- $(1-2.9 \mathrm{~mm})$ and medium-sized $(3-5 \mathrm{~mm})$ follicles (table VIII).

\section{DISCUSSION}

\subsection{Feeding level, body reserves and litter performance}

Sows from both groups lost live weight and fat during lactation, indicating that they mobilized body reserves. Restricted sows lost more body weight and backfat than well-fed sows, in agreement with pre- vious observations $[2,25,50]$. The growth rate of their litters was slightly lower than that of $H$ sows ( 1.88 versus $2.06 \mathrm{~kg} / \mathrm{day}$ ), particularly during the fourth week of lactation (2.15 versus $2.73 \mathrm{~kg} /$ day). Other authors have shown that a restriction in energy and/or protein intake induced a reduction in litter growth $[10,27]$ or had no clear influence $[12,33,50]$. The difference in litter growth observed in our experiment could not be explained by differences in the amount of creep feed eaten by piglets during the fourth week of lactation $(1.32 \mathrm{~kg} /$ litter from $\mathrm{H}$ sows and 
Table VIII. Coefficients of correlation between the metabolic criteria observed 1 day before weaning and some characteristics of the ovaries observed at weaning (W) and $48 \mathrm{~h}$ after weaning $(\mathrm{W}+2)$ in $\mathrm{H}$ and $\mathrm{L}$ sows $(n=12)$.

Lactational

Item GH IGF-I Insulin Cortisol Glucose NEFA Weight loss Fat loss

Ovarian weight

$\begin{array}{lrlllllll}\mathrm{W} & -0.56 & 0.78^{* *} & 0.61^{*} & 0.26 & 0.16 & -0.40 & -0.71^{*} & -0.72 * * \\ \mathrm{~W}+2 & 0.08 & 0.46 & 0.56 & 0.30 & 0.55 & -0.16 & -0.48 & -0.51\end{array}$

Maximum follicular diameter

$\begin{array}{llllrrrrr}\mathrm{W} & -0.27 & 0.62 * & 0.13 & -0.00 & -0.18 & -0.53 & -0.66^{*} & 0.51 \\ \mathrm{~W}+2 & -0.35 & 0.81 * * & 0.34 & 0.26 & 0.44 & 0.18 & -0.50 & 0.08\end{array}$

Diameter of the ten largest follicles

$\begin{array}{llllllllr}\mathrm{W} & -0.40 & 0.59 & 0.31 & 0.09 & -0.30 & -0.61^{*} & -0.58^{*} & -0.42 \\ \mathrm{~W}+2 & -0.25 & 0.65^{*} & 0.30 & 0.23 & 0.42 & 0.25 & -0.44 & 0.20\end{array}$

Number of follicles measuring between 1 and $2.9 \mathrm{~mm}$ in diameter
W
$-0.16$
$-0.61$
$-0.38$
$-0.23$
$0.22 \quad 0.03$
0.29
0.19
$\mathrm{W}+2$
0.40
$-0.52-0.35$
$-0.56$
$-0.22-0.26$
0.44
$-0.13$

Number of follicles measuring between 3 and $5 \mathrm{~mm}$ in diameter
$\mathrm{W} \quad-0.07$
0.09
0.52
0.32
0.17
$-0.29$
$-0.51$
$-0.55$
$\mathrm{W}+2 \quad-0.55$
$0.32-0.02$
0.46
$-0.21 \quad-0.25$
$-0.38$
$-0.10$

Mean IGF-I in fluid of follicles measuring at least $3 \mathrm{~mm}$ in diameter
W
0.05
$0.91 * * * 0.39$
0.22
$0.52-0.07$
$0.07-0.47$
$\mathrm{W}+2 \quad-0.63 * \quad 0.94 * * * 0.19$
0.28
0.07
$-0.47$
$-0.41$
$-0.47$
$-0.81 * * \quad-0.25$

$*: P<0.05, * *: P<0.01, * * *: P<0.001$.

$1.17 \mathrm{~kg} /$ litter from L sows). Therefore, it is likely that during the first 3 weeks of lactation, the sows mobilized body reserves to support milk production, whereas, during the fourth week of lactation, since the body reserves were depleted, the nutrient supply to the mammary gland was insufficient and the milk yield decreased $[7,27]$.

\subsection{Metabolites}

High concentrations of plasma NEFA are considered to reflect high rate of fat mobilization [18]. Therefore, the higher increase in levels of NEFA before the afternoon meal found in $\mathrm{L}$ sows during lactation indicates that they mobilized more fat reserves than $H$ sows $[32,41]$. This mobilization stopped after piglet removal since NEFA concentrations decreased $24 \mathrm{~h}$ after weaning in the restricted sows. In the well-fed sows, the mean concentrations of NEFA were similar in late lactation and $24 \mathrm{~h}$ after weaning, suggesting that their catabolic state during lactation was moderate. Our data indicated that concentrations of NEFA were relatively high on the day of weaning, whatever the level of feeding. This increase in plasma NEFA concentrations might result from the cessation of NEFA uptake by the mammary gland, although previous studies have shown a very low uptake of plasma NEFA by the mammary 
gland of the sow $[28,46]$. Indeed, Boyd et al. [9] suggested that plasma NEFA probably contribute to milk synthesis in sows with a negative energy balance, in agreement with data from Dourmad (pers. comm.) and with the observations of Noblet and Etienne [33], showing that the fat content of milk is increased in energyrestricted sows. The increase in plasma NEFA observed on the day of weaning may also result from the release of NEFA synthesized in the mammary gland when milk excretion ceased into the maternal blood. Such a release was previously reported by Hartmann et al. [22] for lactose, but it started only $18 \mathrm{~h}$ after piglet removal. To our knowledge, no similar data are available for NEFA. Finally, these high concentrations of NEFA could be related to the stress induced by piglet weaning, since stress-related hormones are lipolytic [5]. However, our results did not show any clear increase in cortisol on the day of weaning, in contrast to findings from De Passillé et al. [15] and Tsuma et al. [48].

In our study, feed restriction did not influence mean concentrations of glucose, in contrast to earlier observations [27, 41]. We found that glucose regulation differed between restricted and well-fed sows during the hours following piglet removal. Increase in plasma concentrations of glucose in $L$ sows on the day of weaning was probably due to the cessation of the glucose uptake by the mammary gland $[2$, $36,46]$. Stress-related hormones may also be implicated, as they induced an increased production of glucose [5]. In $\mathrm{H}$ sows, these effects certainly also exist, but may be cancelled by the decrease in glucose concentrations induced by the reduction by $50 \%$ of feed intake on the day of weaning.

\subsection{Metabolic hormones}

During lactation, compared with the post-weaning period, the sows had high concentrations of GH. These high levels can be related, at least in part, to the neuroendocrine stimuli elicited by the piglets during suckling [42]. Negative energetic balance could also contribute to increasing GH concentration during lactation, particularly in L sows [3, 12]. As suggested by Boyd et al. [9] and Quesnel and Prunier [38], the high concentration of GH may allow higher mobilization of fat tissue and favour the preferential drive of the nutrients towards the mammary gland. IGF-I levels were lower in $L$ than in $\mathrm{H}$ sows during lactation despite slightly higher GH levels, which suggests an uncoupling of IGF-I secretion from GH secretion under nutrient deficit, as observed in restricted growing pigs [11] and in lactating cows [44]. In well-fed multiparous sows, Schams et al. [45] suggested that the uncoupling between IGF-I and GH secretions was absent. In restricted lactating sows, the uncoupling of IGF-I from $\mathrm{GH}$ secretion may favour protein mobilization from muscle tissue. Higher levels of IGF-I observed in $\mathrm{H}$ sows may reduce levels of $\mathrm{GH}$, through negative feed-back activity [6]. After weaning, concentrations of GH declined, while concentrations of IGF-I did not change. Similar latency in IGF-I responses to changing metabolic state around weaning has been reported $[37,50]$. Since IGF-I has been demonstrated to stimulate follicular growth and maturation [1], these findings strongly support the hypothesis of Zak et al. [50], that the delayed response in IGFI status after weaning represents a metabolic sequelae of lactational catabolism, which negatively affects ovarian function.

Circulating levels of insulin are closely regulated by the amount of carbohydrates eaten by the animal. This could explain the decrease in insulin concentrations in $\mathrm{H}$ sows between the day before weaning and the day of weaning, since the feed allowance was reduced from 6 to $3 \mathrm{~kg}$. This also explains that during lactation, the mean concentration of insulin was lower in restricted than in well-fed sows. 
As insulin inhibits lipolysis, the low concentrations observed in L sows may facilitate the mobilization of fat tissue.

The lack of influence of feed intake on cortisol concentration during late lactation was unexpected, since Baidoo et al. [3] reported a higher concentration of cortisol in restricted than in well-fed sows on day 28 of lactation. In our study, the concentration of cortisol was higher in late lactation and on the day of weaning than on the day after weaning. This may be due to the neuroendocrine reflexes induced by suckling during lactation and to the stress caused by piglet removal on the day of weaning [15].

\subsection{Relationship between metabolic changes and reproductive performance}

Correlation coefficients indicate a positive relation between insulin level and $\mathrm{LH}$ pulsatility, as previously suggested in cyclic gilts and in lactating sows [14, 19, 47]. The lowered concentration of insulin in L sows may have induced the decrease in the frequency of LH pulses. This observation supports our previous hypothesis that intense nutritional deficit during lactation constitutes an additional inhibitory factor of the hypothalamo-pituitary-ovarian axis, the primary one being the suckling-induced inhibition [38]. The positive correlation between GH and FSH may be related to a lower negative feedback exerted by the ovaries on FSH secretion in $\mathrm{L}$ sows, rather than a relationship of cause and effect. Although cortisol has been reported to inhibit the preovulatory LH surge and decrease the $\mathrm{LH}$ response to $\mathrm{GnRH}$, it may have a positive influence on basal LH secretion $[4,34]$.

The significant correlations existing between weight loss during lactation and some ovarian characteristics at weaning emphasize that ovaries were affected by the amplitude of the nutritional deficit during lactation. Detailed analysis shows clear relationships between ovarian macroscopic characteristics at weaning and 2 days after on the one hand and plasma IGF-I level in late lactation on the other. The high correlation existing between plasma and follicular IGF-I supports the observation of simultaneous variations in peripheral and ovarian IGF-I. This may be explained by a lower transfer of circulating IGF-I into the follicles and/or by a decreased local production of IGF-I in restricted sows. Therefore, we suggest that the uncoupling between GH and IGF-I secretion observed at the peripheral level exists also at the ovarian level.

It can be concluded that feed intake during lactation clearly affects circulating concentrations of insulin and hormones of the somatotropic axis in primiparous sows, whereas cortisol concentrations are poorly modified. These metabolic adjustments favour mobilization of body reserves in order to support milk production. However, they become less efficient in late lactation when maternal body reserves are depleted. These adjustments are likely to be involved in the lower ovarian activity at and after weaning. Our data support that insulin deficit during lactation could play a role in the inhibition of $\mathrm{LH}$ pulsatility while IGF-I deficit during lactation and after weaning may have detrimental effects on ovaries, via gonadotrophin-independent pathways.

\section{ACKNOLEDGEMENTS}

The authors wish to acknowledge Y. Lebreton for performing the surgical procedures, J. Lebost, H. Renoult, D. Boutin and J.C. Hulin for taking care of the animals and F. Giovanni for technical assistance. 


\section{REFERENCES}

[1] Adashi E.Y., Resnick C.E., D'Ercole A.J., Svoboda M.E., Van Wyk J.J., Insulin-like growth factors as intraovarian regulators of granulosa cell growth and function, Endocrine Rev. 6 (1985) 400-420.

[2] Armstrong J.D., Britt J.H., Kraeling R.R., Effect of restriction of energy during lactation on body condition, energy metabolism, endocrine changes and reproductive performance in primiparous sows, J. Anim. Sci. 63 (1986) 1915-1925.

[3] Baidoo S.K., Lythgoe E.S., Kirkwood R.N., Aherne F.X., Foxcroft G.R., Effect of lactation feed intake on endocrine status and metabolite levels in sows, Can. J. Anim. Sci. 72 (1992) 799-807.

[4] Barb C.R., Kraeling R.R., Rampacek G.B, Fonda E.S., Kiser T.E., Inhibition of ovulation and $\mathrm{LH}$ secretion in the gilt after treatment with ACTH or hydroxycortisone, J. Reprod. Fert. 64 (1982) 85-92.

[5] Baxter J.D., Forsham. P.H., Tissue effects of glucocorticoids, Am. J. Med. 53 (1972) 573-590.

[6] Berelowitz M., Szabo M., Frohman L.A., Somatomedin-C mediates growth hormone negative feedback by effects on both the hypothalamus and the pituitary, Science 212 (1981) 1279-1281.

[7] Black J.L., Mullan B.P., Lorschy M.L., Giles L.R., Lactation in the sow during heat stress, Livest. Prod. Sci. 35 (1993) 153-170.

[8] Booth P.J., Metabolic influences on hypothalamo-pituitary-ovarian function in the pig, J. Reprod. Fert. 40 (suppl.) (1990) 89-100.

[9] Boyd R.D., Kensinger R.S., Harrell R.J., Bauman D.E., Nutrient uptake and endocrine regulation of milk synthesis by mammary tissue of lactating sows, J. Anim. Sci. 73 (suppl. 2) (1995) 36-56.

[10] Brendemuhl J.H., Lewis A.J., Peo E.R.J., Effect of protein and energy intake by primiparous sows during lactation on sow and litter performance and sow serum thyroxine and urea concentrations, J. Anim. Sci. 64 (1987) 1060-1069.

[11] Buonomo F.C., Baile C.A., Influence of nutritional deprivation on insulin-like growth factor I, somatotropin, ans metabolic hormones in swine, J. Anim. Sci. 69 (1991) 755-760.

[12] Carroll C.M., Lynch P.B., Boland M.P., Spicer L.J., Austin F.H., Leonard N., Enright W.J., Roche J.F., The effects of food intake during lactation and post weaning on the reproductive performance and hormone and metabolite concentrations of primiparous sows, Anim. Sci. 63 (1996) 297-306.
[13] Chilliard Y., Revue bibliographique : variations quantitatives et métabolisme des lipides dans les tissus adipeux et le foie au cours du cycle gestation-lactation, Reprod. Nutr. Dev. 27 (1987) 327-398.

[14] Cox N.M., Stuart M.J., Althen T.G., Bennett W.A., Miller H.W., Enhancement of ovulation rate in gilts by increasing dietary energy and administrating insulin during follicular growth, J. Anim. Sci. 64 (1987) 507-516.

[15] De Passillé A.M.B., Robert S., Dubreuil P., Pelletier G., Brazeau P., Effect of hypothalamic factor treatments on the behaviour of sows during lactation and on their behavioural and cortisol responses to weaning, Appl. Anim. Behav. Sci. 27 (1990) 231-242.

[16] Dourmad J.Y., Ingestion spontanée d'aliment chez la truie en lactation : de nombreux facteurs de variation, Inra Prod. Anim. 1 (1988) 141-146.

[17] Dourmad J., Etienne M., Prunier A., Noblet J., The effect of energy and protein intake of sows on their longevity: a review, Livest. Prod. Sci. 40 (1994) 87-97.

[18] Dunshea F.R., Harris D.M., Bauman D.E., Boyd R.D., Bell A.W., Effect of somatotropin on nonesterified fatty acid and glycerol metabolism in growing pigs, J. Anim. Sci. 70 (1992) 132-140.

[19] Flowers B., Martin M.J., Cantley T.C., Day B.N., Endocrine changes associated with a dietary-induced increase in ovulation rate (flushing) in gilts, J. Anim. Sci. 67 (1989) $771-778$.

[20] Foxcroft G.R., Nutritional and lactational regulation of fertility in sows, J. Reprod. Fert. suppl. 45 (1992) 113-125.

[21] Foxcroft G.R., Aherne F.X., Clowes E.C., Miller H., Zak L., Sow fertility: the role of suckling inhibition and metabolic status, in: Ivan M. (Ed.), Animal Science Research and Development, Center for Food and Agriculture Canada, Ottawa, Canada, 1995, pp. 377-388.

[22] Hartmann P.E., Whiteley J.L., Willcox D.L., Lactose in plasma during lactogenesis, established lactation and weaning in sows, J. Physiol. 347 (1984) 453-463.

[23] I'Anson H., Foster D.L., Foxcroft G.R., Booth P.J., Nutrition and reproduction, Oxford Rev. Reprod. Biol. 13 (1991) 239-311.

[24] King R.H., Nutritional anoestrus in young sows, Pigs News Information 8 (1987) 15-22.

[25] King R.H., Williams I.H., The effect of nutrition on the reproductive performance of firstlitter sows.v 1. Feeding level during lactation and between weaning and mating, Anim. Prod. 38 (1984) 241-247.

[26] Kirkwood R.N., Aherne F.X., Energy intake, body composition and reproductive performance of the gilt, J. Anim. Sci. 60 (1985) 1518-1529. 
[27] Koketsu Y., Dial G.D., Pettigrew J.E., Marsh W.E., King V.L., Influence of imposed feed intake patterns during lactation on reproductive performance and on circulating levels of glucose, insulin, and luteinizing hormone in primiparous sows, J. Anim. Sci. 74 (1996) 1036-1046.

[28] Linzell J.L., Mepham T.B., Annison E .F., West C.E., Mammary metabolism in lactating sows: arteriovenous differences of milk precursors and the mammary metabolism of $\left[{ }^{14} \mathrm{C}\right]$ glucose and $\left[{ }^{14} \mathrm{C}\right]$ acetate, J. Nutr. 23 (1969) 319-332.

[29] Louveau I., Bonneau M., Effect of a growth hormone infusion on plasma insulin-like growth factor-I in Meishan and Large White pigs, Reprod. Nutr. Dev. 36 (1996) 301-310.

[30] Louveau I., Bonneau M., Salter D.N., Agerelated changes in plasma porcine growth hormone $(\mathrm{GH})$ profiles and insulin-like growth factor-I (IGF-I) concentrations in Large White and Meishan pigs, Reprod. Nutr. Dev. 31 (1991) 205-216.

[31] Meunier-Salaün M.C., Gort F., Prunier A., Schouten W.P.G., Behavioural patterns and progesterone, cortisol and prolactin levels around parturition in European (Large-White) and Chinese (Meishan) sows, Appl. Anim. Behav. Sci. 31 (1991) 43-59.

[32] Mullan B.P., Close W.H., Metabolic and endocrine changes during the reproductive cycle of the sow, in: Batterham E.S. (Ed.), Manipulating Pig Production III, Australasian Pig Science Association, Werribee, 1991, p. 32.

[33] Noblet J., Etienne M., Effect of energy level in lactating sows on yield and composition of milk and nutrient balance of piglets, $\mathbf{J}$. Anim. Sci. 63 (1986) 1888-1896.

[34] Pearce G.P., Paterson A.M., Hughes P.E., Effect of short-term elevations in plasma cortisol concentration on $\mathrm{LH}$ secretion in prepubertal gilts, J. Reprod. Fert. 83 (1988) 413-418.

[35] Prunier A., Martin C., Mounier A.M., Bonneau M., Metabolic and endocrine changes associated with undernutrition in the peripubertal gilt, J. Anim. Sci. 71 (1993) 1887-1894.

[36] Prunier A., Dourmad J.Y., Etienne M., Feeding level, metabolic parameters and reproductive performance of primiparous sows. Livest, Prod. Sci. 37 (1993) 185-196.

[37] Prunier A., Messias de Bragança M., Le Dividich J., Influence of high ambient temperature on performance of reproductive sows, Livest. Prod. Sci. 52 (1997) 123-133.

[38] Quesnel H., Prunier A., Endocrine bases of lactational anoestrus in the sow, Reprod. Nutr. Dev. 35 (1995) 395-414.
[39] Quesnel H., Prunier A., L'ovulation après le tarissement des truies : mécanismes physiologiques et facteurs de variation, Inra Prod. Anim. 8 (1995) 165-176.

[40] Quesnel H., Pasquier A., Mounier A.M., Prunier A., Influence of feed restriction during lactation on gonadotropic hormones and ovarian development in primiparous sows, $\mathbf{J}$. Anim. Sci. 76 (1998) 856-863.

[41] Rojkittikhun T., Einarsson S., Uvnäs-Moberg K., Edqvist L.E., Body weight loss during lactation in relation to energy and protein metabolism in standard-fed primiparous sows, J. Vet. Med. A 40 (1993) 249-257.

[42] Rushen J., Foxcroft G., DePassillé A.M., Nursing-induced changes in pain sensitivity, prolactin and somatotropin in the pig, Physiol. Behav. 53 (1993) 265-270.

[43] SAS, SAS User's Guide: Statistics, Version 6.11 Ed., SAS Inst. Inc., Cary, NC, 1990.

[44] Schams D., Graf F., Graule B., Abele M., Prokopp S., Hormonal changes during lactation in cows of three different breeds, Livest. Prod. Sci. 27 (1991) 285-296.

[45] Schams D., Kratzl W.D., Brem G., Graf F., Secretory pattern of metabolic hormones in the lactating sow, Exp. Clin. Endocrinol. 102 (1994) 439-447.

[46] Spincer J., Rook J.A.F., Towers K.G., The uptake of plasma constituents by the mammary gland of the sow, Biochem. J. 111 (1969) 727-732.

[47] Tokach M.D., Pettigrew J.E., Dial G.D., Wheaton J.E., Crooker B.A., Johnston L.J., Characterization of luteinizing hormone secretion in the primiparous, lactating sow: relationship to blood metabolites and return-toestrus interval, J. Anim. Sci. 70 (1992) 2195-2201.

[48] Tsuma V.T., Einarsson S., Madej A., Lundeheim N., Hormone profiles around weaning in cyclic and anoestrous sows, J. Vet. Med. A 42 (1995) 153-163.

[49] Verstegen M.W.A., Mesu J., Van Kempen G.J.M., Geerse C., Energy balance of lactating sows in relation to feeding level and stage of lactation, J. Anim. Sci. 60 (1985) 731-740.

[50] Zak L.J., Cosgrove J.R., Aherne F.X., Foxcroft G.R., Pattern of feed intake and associated metabolic and endocrine changes differentially affect postweaning fertility in primiparous lactating sows, J. Anim. Sci. 75 (1997) 208-216. 